\title{
Effects of Sugarcane's Bagasse Ash Additive on Portland Cement Properties
}

\author{
Yasir Awad Allah Mohamed ${ }^{1}$, Shihab Ali Khalifa ${ }^{2}$, Salah Eldeen Fadoll Hegazi ${ }^{1,3}$, \\ Hassan Abd Elwahab ${ }^{4}$ \\ ${ }^{1}$ Chemical Engineering Department Engineering College, Elimam Elmahdi University, Kosti, Sudan \\ ${ }^{2}$ Nile Cement Factory, Kosti, Sudan \\ ${ }^{3}$ Chemical Engineering Department, Jazan University, Jazan, Saudi Arabia \\ ${ }^{4}$ Mechanical Engineering Department Engineering College, Elimam Elmahdi University, Kosti, Sudan
}

Email address:

salahhegazi2003@yahoo.com (S. E. F. Hegazi)

\section{To cite this article:}

Yasir Awad Allah. Mohamed, Shihab Ali Khalifa, Salah Eldeen Fadoll Hegazi, Hassan Abd Elwahab. Effects of Sugarcane's Bagasse Ash Additive on Portland Cement Properties. International Journal of Sustainable Development Research. Vol. 3, No. 6, 2017 , pp. 85-89. doi: $10.11648 /$ j.ijsdr.20170306.14

Received: September 23, 2017; Accepted: October 20, 2017; Published: December 27, 2017

\begin{abstract}
The utilization of agricultural waste produced by different industrial processes has attracted the researchers attention. In this paper the influence of sugarcane bagasse ash (SCBA) as an additive in enhancing the properties of the portland cement was investigated. Thus, the ordinary Portland cement (OPC) was partially modified by adding fine sugarcane bagasse ash. The bagasse ash was sieved through No. 600 sieve, then the concrete and mortar mixtures samples were modified by adding $0 \%, 5 \%, 10 \%, 15 \%$, and $20 \%$ of BA respectively. The physical characteristics and chemical composition of the bagasse ash and cement mixtures analyzed and tested in Nile Cement Company). The obtained samples were examined and compared with the ordinary cement. The result revealed that addition of bagasse ash to cement up to $15 \%$ has improved the compressive strength of mortar. While the addition of $20 \%$ bagasse ash to cement results in decreasing the soundness of the cement and improving its fineness.
\end{abstract}

Keywords: Utilization, Baggase, Cement, Fittness, Portland, Ash

\section{Introduction}

At the end of the eighties of the last century a looming, long-term scarcity of raw material and increasing environmental awareness initiated a rethinking process that led to new priorities in waste materials management. Numerous low, directives and regulations have now been enacted with the aim of minimizing the consumption of raw materials and energy, saving earth from pollution and maximizing the re-use of materials. For the cement industry this resulted in a social contract for sustainable materials and thermal utilization of waste materials in order to conserve the natural resources and not to reduce the quantities deposited in landfills. In general, a large number of materials are available for use as replacement to other raw materials or as correction materials. These include waste materials of industrial processing. Hence, the type of waste material that could be reused have to be first assessed on the basis of the facilities at the individual sites. Cement production is however harms the environment due to carbon dioxide emission. Reducing the cement production hazardous and maintaining a sustainable green environment has been an annoying concern in the development of construction materials. Modifying Portland cement with a percentages of pozzolana has been reported as one of the good alternative [7]. Each year, the concrete industry produces about 12 billion tones of concrete, and uses about 2.86 billion tones of Portland cement worldwide. Pozzolana material when used in mortar and concrete work improved durability which is the ability of concrete to resist weathering action, chemical attack and abrasion. Also it brings in other technical advantages such as low heat of hydration and high ultimate strength. The higher strength of 
concrete with pozzolana at later ages is as a result of the Pozzolana reactions which increases the amount of calcium silicate hydrates $(\mathrm{C}-\mathrm{S}-\mathrm{H})$ while diminishing $\mathrm{Ca}(\mathrm{OH})_{2}$ [12]. In this paper, it is intended to use the sugarcane bagasse ash waste as an additive material to improve the Portland cement properties.

\section{Materials}

\subsection{Fresh Clinker}

It was obtained from Nile Cement factory. Clinker particles having size between $0.8 \mathrm{~cm}$ to $1.5 \mathrm{~cm}$ of blackish gray color and intermediate hardness were used in conducting the experimental work. The density of clinker is between $1.2 \mathrm{Kg} / \mathrm{Liter}$ to $1.4 \mathrm{Kg} / \mathrm{Liter}$.

\subsection{Raw Gypsum}

This material was obtained from Port Sudan city, and it is used by the same factory to produce the cement. It is also used in performing the tests. The particle size employed is in the range between $10 \mathrm{~mm}$ to $15 \mathrm{~mm}$. The material density is $1.2 \mathrm{~g} / \mathrm{cm}^{3}$.

\subsection{Sugar Cane Bagasse Ash (SCBA)}

One sample of Bagasse Ash from Assalaya Sugar factory which located in Nile White State of Sudan was chosen from the three types of BA with respect to their chemical compositions. The obtained ash was further ground in a Los Angeles abrasion machine until the particles retained on 45 $\mu \mathrm{m}$-sieves were less than $5 \%$. The chemical composition of SCBA determined by traditional testing method.

Table 1. The employed raw materials chemical composition

\begin{tabular}{|c|c|c|c|c|c|c|}
\hline \multirow{3}{*}{ Component } & \multicolumn{6}{|l|}{ Material } \\
\hline & \multirow{2}{*}{ Clinker (\%wt) } & \multirow{2}{*}{ Gypsum (\%wt) } & \multicolumn{4}{|c|}{ Bagasse Ash (\%wt) } \\
\hline & & & Sample (1) & Sample (2) & Sample (3) & Average \\
\hline $\mathrm{CaO}$ & 63.57 & 33.60 & 12.6 & 11.48 & 11.20 & 11.76 \\
\hline $\mathrm{SiO}_{2}$ & 22.72 & 5.60 & 65 & 76.06 & 69.96 & 70.34 \\
\hline $\mathrm{Al}_{2} \mathrm{O}_{3}$ & 4.72 & 0.255 & 3.39 & 2.29 & 3.69 & 3.12 \\
\hline $\mathrm{Fe} 2 \mathrm{O} 3$ & 4.58 & 0.399 & 9.17 & 2.79 & 6.92 & 6.29 \\
\hline $\mathrm{MgO}$ & 3.63 & 1.008 & 0.6 & 2.82 & 0.4 & 1.27 \\
\hline $\mathrm{SO} 3$ & 0.5 & 41.93 & 0.1 & 0.4 & 0.5 & 0.33 \\
\hline L.O.I & 0.63 & - & 9.02 & 3.73 & 7.54 & 6.76 \\
\hline F.W & - & 0.07 & - & - & - & - \\
\hline C.W & - & 17.24 & - & - & - & - \\
\hline Total & 99.98 & 100.10 & & & & \\
\hline
\end{tabular}

\section{Experimental Methods}

\subsection{Materials Preparation}

There are no specifications or test methods to determine the grind ability of raw materials. Many types of grinding machines were developed to grind the clinkers such as; ball mill, tube mill, rod mill. In this study, the ball type grinder was used. The clinkers, Bagasse ash and gypsum were ground separately up to three different Blaine fineness values; $3000,3500,4000 \mathrm{~cm}^{2} / \mathrm{g}$. After grinding, clinkers were mixed with the Bagasse ash in there different amount; $5 \%, 10 \%, 15 \%$ and $20 \%$ by weight replacement. The gypsum was used at only $\% 4$ by weight in the production of all cements.

\subsection{Compressive Strength of Mortar}

The test was performed on nine Prepared cubes having internal length of $7.07 \mathrm{~cm}$, face area of $50 \mathrm{~cm}_{2}$ and walls angles of 90 degree. The preparation of mortar mixture was made by adding $185 \mathrm{~g}$ cement to $555 \mathrm{~g}$ sand at ratio of $1: 3$. Then the mixture was moisturized by adding $10 \%$ of weight water $(74 \mathrm{ml})$. Firstly, cement and sand were mixed for a minute, and then water was added. Secondly, the mortar was well stirred for two minutes using a mixing device, and then the template was placed on a vibration machine (speed of vibration 400 - 1200 shakes per minute) for two minutes to squeeze mortar. Then the tested cubes were placed in a mold, having $90 \%$ relative humidity and $20^{\circ} \mathrm{C}$ temperature for 24 hours. Finaly, the test cubes were removed from the mold and marked by numbers, and then were immediately immersed in water until they are tested. The compressive strength is determined after two days, after 7 days and after 28 days [1].

\subsection{Soundness Test (Expansion)}

The Lech atelier is used to measure the expansion of the cement samples. The test consists of an open steel cylinder with a capacity of $100 \mathrm{~g}$. A mixture composes of $100 \mathrm{~g}$ cement and $27 \%$ water of its weight were well stirred. Then Lech atelier molds was put in a glass base and filled with standard soft cement dough. The mold was left for 24 hours in a basin with / without immersing it in water, so that the temperature must be $20^{\circ}$ and humidity should be $90 \%$. Then the distance between the two indices is measured by the ruler. After then the mold is placed in a water bath for one hour and the distance between the two indices is calculated again. The value of expansion was considered as the difference between the two readings [1].

\subsection{Fineness by Blaine Air Permeability Test}

The principle of the test depends on impelled air penetrate into the compressed cement barriers within known dimensions (permeability cell). The estimated cement sample 
weight is $2.9005 \mathrm{gm}$. It was placed inside the cell between two filtering papers by employing funnel and cement pressure using a plunger. Then it was placed on the top of mano metric tube. The tube internal aspects and the outer edges of the cell were filled with wax to prevent the passage of air between the blanks. after filling the internal aspects of the tube and also the outer edges of the cell with wax to prevent the passage of air between the blanks. Air was pull up from inside the cell by blower, which in turn raises the level of the liquid within the tube. The water level goes down from the top gradually depending on the air pushing force. The time length that takes the liquid to drop was recorded by using stopwatch. For confirmation, the experiment was replicated three times [17].

\section{Test Results and Discussion}

Table 2. The Chemical Composition of the Modified Portland cement with Bagasse Ash.

\begin{tabular}{|c|c|c|c|c|c|}
\hline \multirow{3}{*}{ Component } & \multicolumn{5}{|l|}{ Material } \\
\hline & \multicolumn{5}{|c|}{ Portland Pozzolana Cement Replace with Bagasse Ash } \\
\hline & Sample (1) 0\%wt & Sample (2) 5\%wt & Sample (3) $10 \% \mathrm{wt}$ & Sample (4) $15 \%$ wt & Sample (5) $20 \% w t$ \\
\hline $\mathrm{CaO}$ & 64.40 & 61.88 & 61.04 & 57.68 & 54.60 \\
\hline $\mathrm{SiO} 2$ & 21.24 & 23.38 & 23.42 & 25.72 & 27.80 \\
\hline $\mathrm{A} 12 \mathrm{O} 3$ & 04.84 & 04.71 & 04.59 & 04.46 & 04.97 \\
\hline $\mathrm{Fe} 2 \mathrm{O} 3$ & 04.38 & 04.18 & 04.38 & 04.18 & 04.19 \\
\hline $\mathrm{MgO}$ & 03.02 & 03.02 & 03.02 & 03.22 & 03.42 \\
\hline L.O.I & 01.88 & 01.51 & 02.05 & 02.39 & 03.20 \\
\hline Total & 99.76 & 100.16 & 100.17 & 100.34 & 99.85 \\
\hline
\end{tabular}

The OPC (sample1) had a $\mathrm{CaO}$ and $\mathrm{SiO}_{2}$ content of $64.40 \%$ and $21.24 \%$ respectively (Table 2 ). The percentage weight sum of these compounds in the above sample is $85.64 \%$ with loss on ignition of $1.88 \%$. Thus, this value of loss on ignition well satisfies the standard limit of EN 196-1. In general, the OPC is chemically considered as a good cement. However, adding bagasse Ash to the cement changes its chemical composition, and consequently improves the cement properties. From table 2, it is apparent that the amount of bagasse ash added to the cement increase the percentage weight of Silica oxide $\left(\mathrm{SiO}_{2}\right)$ in the OPC. It is also observed that the Sulphur trioxide $\left(\mathrm{SO}_{3}\right)$ was significantly increased with increasing the percentage weight of the bagasse ach in cement, while the magnesium oxide $(\mathrm{MgO})$ was increased moderately and still within the standard limit of EN 196-1. This may result in improving the cement strength while the loss on ignition is kept within the standard limit of EN 196-1.

\subsection{Fineness}

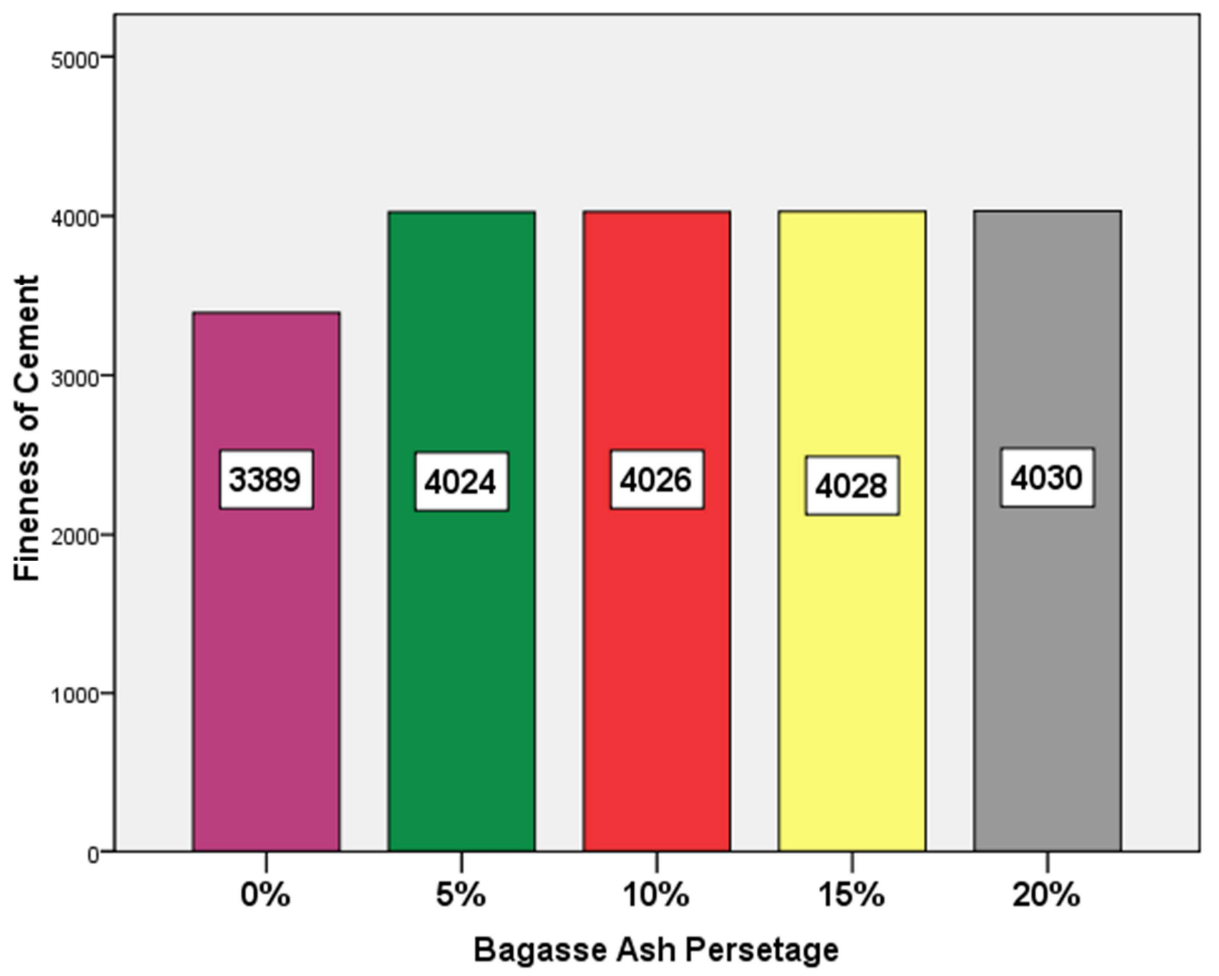

Figure 1. Relationship between Bagasse Ash added and Fineness of Cement. 
It can be realized that the ordinary Portland cement obtained the least Blaine index of $3389 \mathrm{Cm}^{2} / \mathrm{g}$ (Figure 1). Whereas the Portland pozzolana cement recorded the highest values. The Blaine indices of pozzolana cement increased as Bagasse ash content increased from 5 to $20 \%$. This indicates that the surface area of the mixture increased as the pozzolana content increased. Therefore, it is expected that addition of bagasse ash to the cement will enhance its compressive strength as high fineness cement usually gives high Compressive strength

\subsection{Compressive Strength of Mortar}

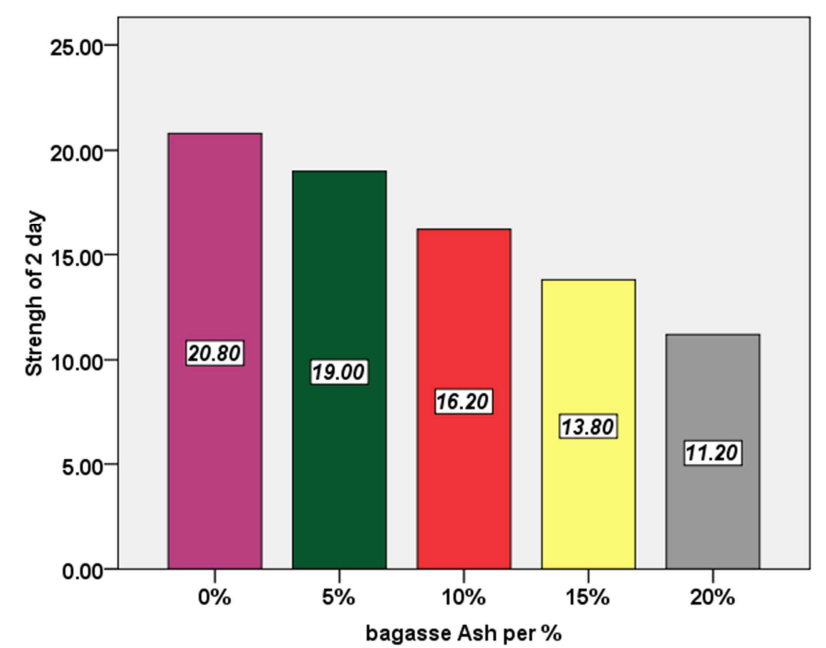

Figure 2. Relationship between Bagasse Ash added and Compressive Strength for two days of mortar.

Figures 2 and 3, represent the results obtained from the tested samples (after being immersed in water for 2 and 28 days respectively. It is evident that the measured the compressive strength of mortar increased with adding 5\% up to $15 \%$ bagasse ash to the cement (Figure 3 ). When the amount of bagasse ash in cement increased up to $20 \%$, the compressive strength of cement was decreased. The result is different for the samples immersed in water for Fewer days. For the samples that took seven days in water, no significant effect of adding bagsses ash on the compressive strength of the cement was realized. However, in the case of the samples being for two days in water, addition of bagasse ash dramatically reduces the cement compressive strength (Figure 2).

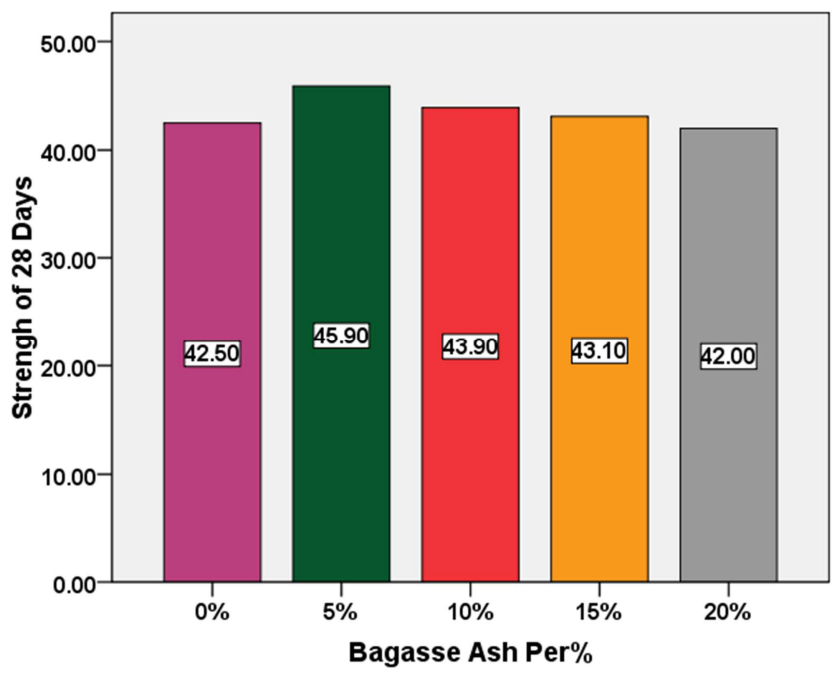

Figure 3. Relationship between Bagasse Ash added and Compressive Strength for 28 Days of mortar.

\subsection{Soundness}

The results obtained from the tested samples are tabulated in table 3 . The sample1 showed high value of soundness $(7 \mathrm{~mm})$. When pagasse ash was added to the cement the soundness value was decreased almost to zero. This indicates that addition of bagsse ash could highly improved the cement soundness.

Table 3. Soundness of the Portland cement with/without Replacement of Bagasse Ash.

\begin{tabular}{llllll}
\hline \multirow{2}{*}{ Soundness mm } & Sample (1) 0\% & Sample (2) 5\% & Sample (3) 10\% & Sample (4) 15\% & Sample (5) 20\% \\
\cline { 2 - 6 } & 7 & 0 & 0 & 0 & 0 \\
\hline
\end{tabular}

\section{Conclusions}

1. This study used Bagasse Ash as natural pozzolana.

2. Partial replacement of cement by Bagasse Ash increases compressive strength of mortar and concrete.

3. The result shows that the addition of Bagasse Ash improves the compressive strength of mortar up to $15 \%$ addition of bagasse ash.

4. Highest 28-day compressive strength of mortar was obtained using 5\% Bagasse ash.

5. Partial replacement of cement by Bagasse Ash decreases soundness of the cement up to $20 \%$ Bagasse ash adding

6. Improvement of cement fineness whenever increases of Bagasse ash adding up to $20 \%$

\section{Recommendations}

This research studied some of the basic physical and chemical properties of Assalaya sugar factory Bagasse ash as a cement replacing material. However, further studies are required on the following items:

1. Studies should be made using controlled burning of the Bagasse at different temperature and holding time.

2. The effects of different fineness of the Bagasse ash should be studied as well.

3. The Bagasse ash from different sources like, Kenana, Sinaar, Algonaid and the coming new sugar factories should be studied.

Studies should be made to check the pozzolana reaction of 
the Bagasse ash using more advanced methods like X-ray Diffraction (XRD) Analysis.

1. The study recommends the use of another industrial pozzolana like (silica fume, rice husk ash, slag, and fly ash) as replacement of cement.

2. More research needed to define the applicable limits of replacing Bagasse ash of Portland clinker for producing pozzolana cement.

In this study Bagasse Ash mixed with clinker and produces the cement in future study should be Bagasse ash add as aggregate material.

1. Using different type of Bagasse ash from different plants with different physical and chemical properties

2. Make simulation and optimization for designing a model for burning of the different types of bagasse

\section{References}

[1] Abebe Dinku, Construction material laboratory manual, Thesis M.Sc, Addis Ababa university, 2002.

[2] Ahmed. S. F and Shaikh. Z, Portland pozzolana cement from sugar cane bagasse ash. International Technology Publication, London, 1992, pgs 172-179.

[3] Asare Samuel, Comparing the compressive strength of concrete utilizing natural pozzolana as a partial replacement of Portland cement, Thesis HND, School of engineering in Ghana, 2010.

[4] Asma Abd Elhmeed, Nasir Shafig, Compressive strength and microstructure of bagasse ash concrete, Research Journal of Applied sciences Engineering and technology, 2014, pgs 2569-2577.

[5] B. Chatreera, P. Lertwattanaruk, Durability of conventional concrete containing black rise husk ash, Journal of environmental management, 2011, pgs 59-66.

[6] Donald W. Lewis, P. E, Chief engineering, national slag association presented at university of Alabama, Slag cement seminar, 1981.

[7] Dr. T. Roppelt, Rohrdor, Use of alternative raw material for cement clinker production- Cement international magazine, 2006- 36 pgs.
[8] F. M. Lea, The chemistry of cement and concrete, Edwer Arnold (Publishers) Ltd, London, 1970.

[9] F. M. Lea, The chemistry of cement and concrete, $3^{\text {rd }} \mathrm{Ed}$, Chemical Publishing. Company Inc, 1971.

[10] Hakan Avsar, Control optimization and monitoring of Portland cement quality at the ball mill, Thesis M. Sc, Izmir institute of technology school of graduate studies, 2006.

[11] Kiran R. G, Analysis of strength characteristic of black cotton soil using bagasse ash and additives as stabilizer, International Journal of engineering research\& technology, 2013, Issue 7.

[12] Kwabena, Improvement of setting time and early strength development of pozzolana cement through chemical activation, Thesis Ms, University of science and technology, 2012.

[13] Malhotra, V. M and Mehta, Pozzolanic and cementitous material, Amsterdam, Gordon\& Breach, 1996.

[14] Malhotra V. M, Properties of concrete with bagasse ash as fine aggregate, in proc $5^{\text {th }}$ CANMET/ ACI, USA, 1995.

[15] Rafat Siddique, Utilization of industrial by product in concrete, Journal of environmental research and development vol.2. 2008, pgs 4.

[16] R. Srinivasan and K. Sathiya, Experimental study on bagasse ash in concrete, International Journal for service learning in engineering vol.5, 2010, pgs 60-66.

[17] Subramani. T, Senthilkumar. T, Analysis of admixtures and their effects of silica fumes, International journal of modern engineering research, Volume 4- Issue 6 version 4, 2014, pgs 28-36.

[18] Udayashankar D. Hakari, S. C. Puranik, Stabilization of black cotton soils using fly ash, Hubballi- Dharwad Municipal Corporation area, Karnatak, India, 2012, Vol.12 Issue 2.

[19] http://www.concreteproducts.com/art/concrete news development 27/at 14/12/2016, 2: 03 PM.

[20] http://www.fhwa.dof.gov/infrstructure/materialsgap/cement.ht m/at 7/2/2017, 10: 00 AM.

[21] http://www.geocities.com/capeconaveral/launchpad/2095/pozz olana.htm at 22/3/2017, 1: 23 PM.

[22] http://www.scribd.com/doc/39643059/at 1/3/2017, 11: 44 AM. 